Original paper

\title{
Duration of cambial activity is determined by water availability while cambial stimulus is day-length dependent in a Neotropical evergreen species
}

\author{
Natália Oliveira Totti de Lara ${ }^{\mathrm{a}, *}$, Magali Ribeiro da Silva ${ }^{\mathrm{b}}$, Anselmo Nogueira ${ }^{\mathrm{a}, \mathrm{c}}$, \\ Carmen Regina Marcati ${ }^{\mathrm{a}, \mathrm{b}}$ \\ ${ }^{a}$ Programa de Pós-Graduação em Ciências Biológicas (Botânica), Universidade Estadual Paulista (UNESP), Instituto de Biociências de Botucatu, Botucatu, São Paulo, \\ 18618-970, Brazil \\ b Universidade Estadual Paulista (UNESP), Faculdade de Ciências Agronômicas de Botucatu, Botucatu, São Paulo, 18610-307, Brazil \\ ${ }^{\mathrm{c}}$ Universidade Federal do ABC, Centro de Ciências Naturais e Humanas, São Bernardo do Campo, São Paulo, 09606-070, Brazil
}

\section{A R T I C L E I N F O}

\section{Keywords:}

Cordiera concolor

Early spring

Late summer

Tropical species

Soil water availability

\begin{abstract}
A B S T R A C T
Experimental manipulations are essential for understanding the causal factors of plant growth and cambial activity. Here, we studied the potential effect of water availability and natural variation of day length and temperature on cambial activity in Cordiera concolor (Cham.) Kuntze, an evergreen tropical species. Experiments were conducted in a greenhouse using ninety one-year-old plants divided into two groups. Each group was observed for five weeks during two different times of the year (early spring and late summer). Plants were subjected to three distinct water regimes (waterlogging, field capacity and water deficit). Temperature and day length were recorded daily and stem samples were taken weekly during both sampling intervals. Anatomical procedures were used to describe the cambial activity per stem. Our results suggest that soil water content and its influence on cambial activity depend on the time of year, while cambial stimulus was positively related to day length, independent of the time of year. In early spring, cambial activity was stimulated by an increase of day length, regardless of water supply. In contrast, in late summer, cambial dormancy was delayed in waterlogged plants and advanced in plants subjected to a water deficit, followed by decreasing day length. Analyses of the wood anatomy showed that the marginal bands of axial parenchyma were initial. Our study highlights a more complex scenario of plant functioning and its causal factors in tropical systems.
\end{abstract}

\section{Introduction}

Cambial activity in woody plants is influenced by extrinsic factors such as precipitation, day length and temperature (Borchert, 1999) and by intrinsic factors such as plant hormones (Little and Savidge, 1987). The variation of these factors throughout the year may lead to cambial seasonality, which depends on the environment in which the tree grows. Among the extrinsic factors influencing cambial activity, temperature has been considered the most important in cold temperate environments (Begum et al., 2013; Rossi et al., 2013). In tropical environments, cambial activity has been attributed mainly to precipitation, as reported previously for several tropical species by Worbes (1995) and more recently for five tropical species of Thailand (Pumijumnong and Buajan, 2012). For Brazilian species, the active period coincides with the wet season and the dormant period with the dry season (Marcati et al., 2006, 2008).

Most studies on cambial activity in tropical species were conducted on plants from the field, providing information about the temporal patterns of cambial activity throughout the year (see Aljaro et al., 1972; Avila et al., 1975; Dave and Rao, 1982; Worbes, 1995; Rao and Rajput, 1999; Rajput and Rao, 2000, 2001, 2002; Dié et al., 2012; Pumijumnong and Buajan, 2012; Trouet et al., 2012). For example, rainfall and cambial activity were not correlated in Chilean and Californian evergreen shrubs species, and in two of these species the cambial activity was observed in early spring while cambial dormancy in late summer (Avila et al., 1975). Maximum temperature and day length were the most important factors explaining cambial activity in Mexican evergreen species (Yañez-Espinosa et al., 2006). Recently, for Brazilian evergreen species of the Cerrado, a savanna-like ecosystem, day length (de Lara and Marcati, 2016) and temperature (Marcati et al., 2016) were important signals of cambial activity. For a better understanding of the relationship between abiotic factors (water, day length and temperature) and cambial activity, manipulative studies are required that experimentally modify some of these factors.

Experimental research on cambial activity has been limited to temperate species, either investigating the effects of temperature and/

\footnotetext{
* Corresponding author.

E-mail address: natotti@gmail.com (N.O.T. de Lara).
} 
or day length (Wareing and Roberts, 1956; Waisel and Fahn, 1965; Mellerowicz et al., 1992a, 1992b; Oribe and Kubo, 1997; Oribe et al., 2001), or the effects of water availability (Rossi et al., 2009; de Luis et al., 2011; Balducci et al., 2013) on cambial activity. Under limited water availability, cell divisions and expansion of newly produced cells can decrease or even cease (Abe and Nakai, 1999; Abe et al., 2003). Long dry periods during summer may affect cambial activity in threeyear-old seedlings (de Luis et al., 2011); two different water regimes, following a severe drought affect the resumption of cambial activity in four-year-old saplings (Balducci et al., 2013). Thus, recent studies showed the relevance of water availability for cambial activity in temperate species (Rossi et al., 2009; de Luis et al., 2011; Balducci et al., 2013). For tropical species, experimental studies providing a comprehensive view of cambial activity are currently unavailable.

Taking into account that for tropical species: (i) precipitation has been considered the main extrinsic factor related to cambial activity and may limit its activity; (ii) day length and temperature seem to be general signals to cambial activity and (iii) there is a lack of experimental studies on the subject, we investigated the causes of cambial activity variation in Cordiera concolor (Cham.) Kuntze (Rubiaceae), an evergreen shrub that occurs in the Brazilian central plateau (Zappi, 2015). Cambial activity of this species is seasonal (de Lara and Marcati, 2016) with growth markers in its wood (marginal bands of axial parenchyma) (see Sonsin et al., 2014), making it ideal to experimentally investigate growth patterns and their causal factors.

Considering that there is an increase in the frequency and severity of droughts (IPCC, 2014) and that water is a limited resource, we tested the effect of water availability (including water deficit) on cambial activity in association with temperature and day length. We explored four main questions concerning the evergreen tropical species Cordiera concolor: (i) How does cambial activity changes over weeks? (ii) What is the effect of soil water availability on cambial activity? (iii) Is cambial activity related to natural variation of day length and temperature? (iv) Is the formation of axial parenchyma bands in wood initial, terminal or both?

\section{Material and methods}

\subsection{Sources of plant material}

We selected all individuals $(\mathrm{n}=3)$ of $C$. concolor with mature fruits ( $\mathrm{n}=60$ ) from a remnant of the cerrado sensu stricto in Rubião Jr.,
Botucatu, São Paulo, Brazil (S22 $53^{\prime} 29,5^{\prime \prime}$, W48 $29^{\prime} 21^{\prime \prime}$ ) for collecting seeds $(\mathrm{n}=300)$ (Fig. 1A-D). The seeds were germinated in wet filter paper inside acrylic boxes under fluorescent lamps in a germination chamber at $25^{\circ} \mathrm{C} \pm 1{ }^{\circ} \mathrm{C}$ under alternating dark and light periods $(12 \mathrm{~h}$ of dark and $12 \mathrm{~h}$ of light) (Bertani and dos Santos, 2013). After primary root protrusion, we replaced the wet filter paper by vermiculite, adding Hoagland and Arnon (1950) solution and transferred the plants to a greenhouse. Here, the term "plant" refers to the developmental stages beginning with the expansion of the first metaphyll pair (sensu Oliveira, 2001). We characterized metaphylls by analyzing leaf matrices.

\subsection{Experimental design}

Experiments were conducted in a greenhouse of $5 \mathrm{~m}$ width, $3 \mathrm{~m}$ height and $15 \mathrm{~m}$ length. The roof was covered with diffuse polyethylene film $(150 \mu \mathrm{m})$ transparent to long-wave radiation to minimize radiative heating, and walls were covered with shading screen (Supplementary data, Fig. S1A). One-year-old plants were transplanted into plastic pots (volume of one liter) filled with soil collected from the cerrado sensu stricto where $C$. concolor occurs. We selected 90 plants of relatively uniform size $(15.0 \pm 0.6 \mathrm{~cm}$ of height and $2.3 \pm 0.2 \mathrm{~mm}$ of diameter at the collar) for the manipulation of water availability. We conducted the experiment twice with plants of the same age: in early spring, from September 12th to October 17th (see Supplementary data, Table S1), and in late summer, from March 1st to April 5th (see Supplementary data, Table S2). Forty-five plants were used in each sampling interval. These two intervals had variation in day length and temperatures (Fig. 2). We chose these two intervals based on studies of woody species of the Brazilian Cerrado, according to which cambial activity occurs in early spring (Bosio et al., 2016; de Lara and Marcati, 2016; Marcati et al., 2006, 2008, 2016) and cambium dormancy in late summer (de Lara and Marcati, 2016; Marcati et al., 2006, 2016).

To determine the different experimental water treatments, we used a water retention curve according to Richards (1948) (Table 1). In addition, we performed physical and chemical analyses of the soil of the Cerrado area (Supplementary data, Table S3). We divided 45 plants at random into three treatments, 15 plants each, and transferred them to a greenhouse. The treatments were: (i) waterlogged with $21 \%$ humidity in the soil (T1) with plants placed in a tank (Supplementary data, Fig. S1B), where the water level was maintained at a level of $5 \mathrm{~cm}$; (ii) close to field capacity with $8 \%$ humidity in the soil (T2); (iii) dry regime with plants kept at soil water content near wilting point (3\% humidity in the
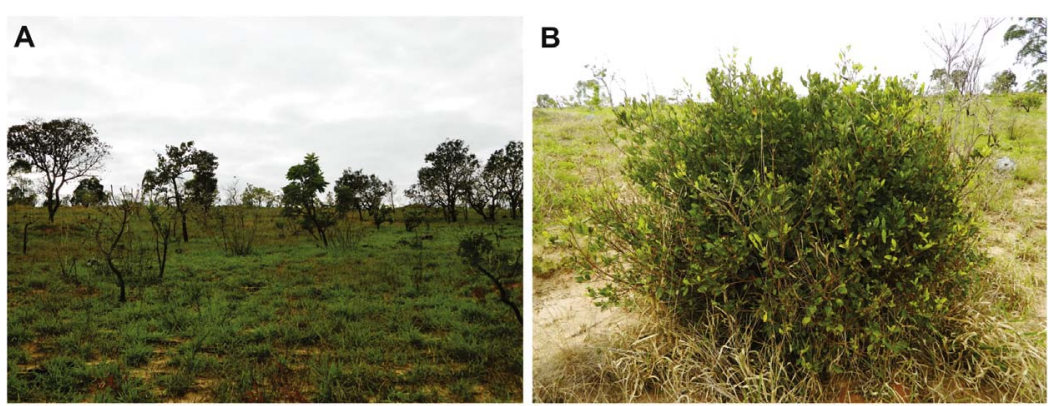

Fig. 1. Cordiera concolor (Cham.) Kuntze (Rubiaceae). A General view of cerrado sensu stricto. B A specimen of $C$. concolor growing in the area. C Flowers. D Mature fruit with violet pericarp (diameter approximately $1 \mathrm{~cm}$ ). (For interpretation of the references to colour in this figure legend, the reader is referred to the web version of this article.)
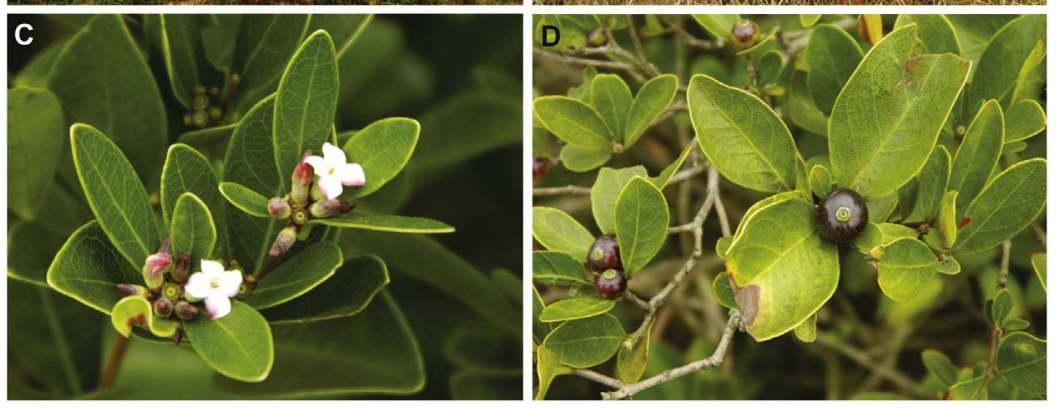


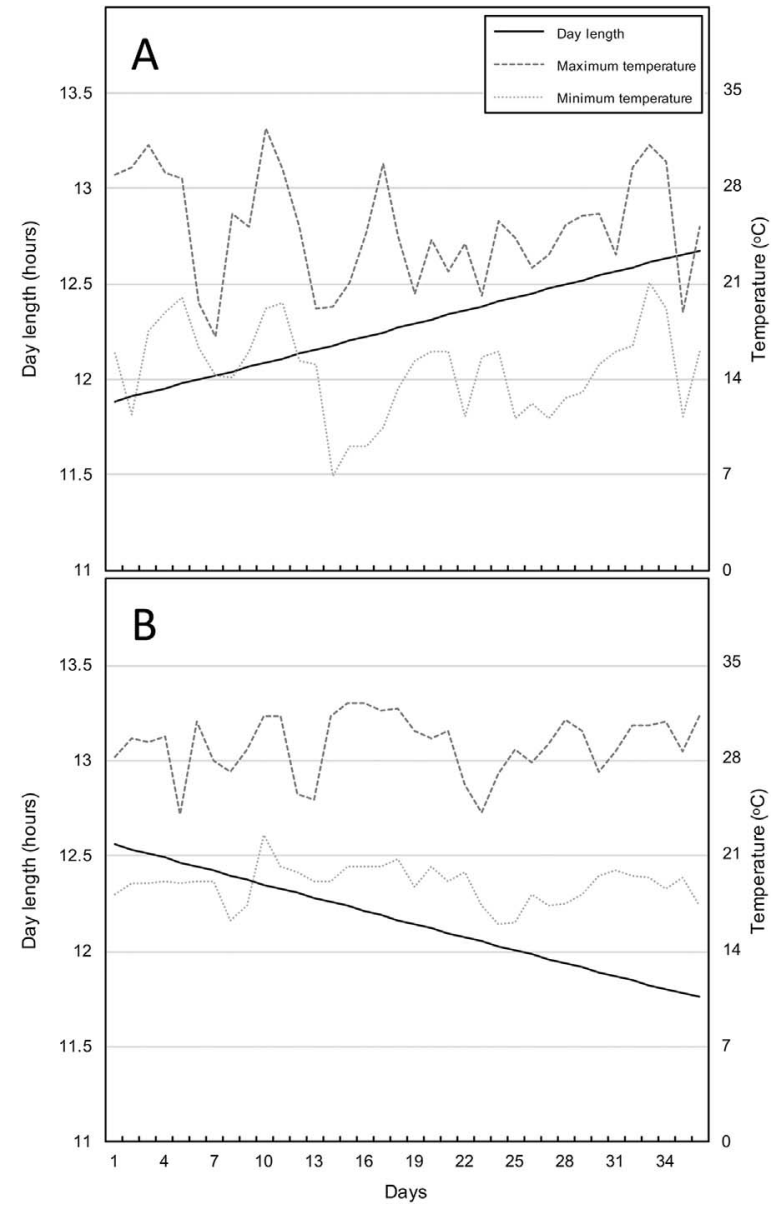

Fig. 2. Temperature (maximum and minimum) and day length for both sampling intervals. A Early spring. B Late summer.

Table 1

Water content in Cerrado soil. Arrows indicate the values selected for the experiment.

\begin{tabular}{lcccccccc}
\hline & \multicolumn{8}{c}{ Soil water retention tension (KPa) } \\
\cline { 2 - 8 } & $\begin{array}{l}\downarrow \\
0\end{array}$ & $\begin{array}{l}\downarrow \\
10\end{array}$ & 30 & 50 & 100 & 300 & 500 & $\begin{array}{c}\downarrow \\
1500\end{array}$ \\
\hline Humidity (\%) & 21 & 8.4 & 5.8 & 4.4 & 4.2 & 3.8 & 3.5 & 3.3 \\
\hline
\end{tabular}

soil) (T3). To maintain treatments of field capacity and dry regime (water deficit), we added water to each pot every day according to the water retention curve. To assess cambial activity, three plants per treatment were sampled during five weeks. All plants were exposed to the same daylight and temperature which depended on the sampling interval.

The consistency of each water treatment over time was evaluated by the weighing method (Klar et al., 1966). This method is based on daily weighing to determine when to irrigate each pot. We determined initial soil moisture by a gravimetric method (Blake, 1965). For each treatment, we determined the weight of the plastic pot, the plant, and the soil, and the weight corresponding to the amount of water for each pot. From the sum of the weights, we determined the weight that each pot should reach in order to irrigate them. This procedure was applied to both sampling intervals.

\subsection{Meteorological data}

We obtained daily minimum and maximum temperatures from the Meteorological Station at Faculdade de Ciências Agronômicas at
UNESP, Botucatu, SP for both intervals (Supplementary data, Table S4; Supplementary data, Table S5). The Meteorological Station is one $\mathrm{km}$ away from the nursery at Faculdade de Ciências Agronômicas where the experiments were conducted. Temperatures from meteorological station were used in this study as they were highly correlated to the greenhouse temperature $(\mathrm{r}=0.94$ for maximum temperature, and $\mathrm{r}=0.97$ for minimum temperature).

The day length data were obtained from the website Time and Date (2015). For the analyses, we used the day length in a decimal scale (see Supplementary data, Table S4; Supplementary data, Table S5).

\subsection{Light microscopy and cambial activity definition}

We obtained samples from the median region of the stem containing the cambial zone and the secondary tissues (secondary xylem and phloem) performing a destructive sampling, with the aid of a stylus, at the end of each week, which were immediately fixed in CRAF III $(10 \%$ chromic acid, glacial acetic acid, 37\% formaldehyde and distilled water) (Berlyn and Miksche, 1976), where they remained for one week. We trimmed small samples of stems and dehydrated them in ethanolic sequence, embedded them in plastic resin according to Bennett et al. (1976), and cut them (transversally and longitudinally) in sections of about $4 \mu \mathrm{m}$ thickness using a semi-automated rotary microtome. We stained the sections with toluidine blue in acetate buffer, $\mathrm{pH} 4.7$, producing a metachromatic stain (O'Brien et al., 1964). In some cases, we sectioned free-hand samples and stained them with a safranin/astra blue solution. We obtained images under a light microscope equipped with a digital camera.

We identified cambial activity by mitotic figures and the presence of very thin, recently formed, periclinal cell walls (Esau, 1977; Evert, 2006). In addition, we selected 15 sequential radial rows in the cambial zone in transverse sections in each plant and counted all recently formed periclinal cell walls (Supplementary data, Table S6; S7). We used the term "cambial zone" to describe the radial rows of fusiform cells and ray initials associated with their derivatives (between differentiating or differentiated xylem and phloem cells).

\subsection{Data analyses}

We analyzed cambial activity separately for the two sampling intervals (early spring and late summer). For each interval, we analyzed the relationship between cambial activity and time, a statistical test not related to any causal hypotheses. Next, we examined the relationship between cambial activity and soil water availability, temperature (maximum and minimum) and day length in accordance with previous causal hypotheses (e. g. Bosio et al., 2016; de Lara and Marcati 2016; Marcati et al., 2016). Due to the potential correlation among temperature and day length, we first verified the product-moment correlation coefficient $(r)$ among them. Because correlation coefficients only show pairwise correlations, we also used variance inflation factors to assess which explanatory variables are collinear and should be dropped before starting analyses (Zuur et al., 2009).

In all cases, we used generalized linear models (GLM), when variance was not constant, and/or errors were not distributed normally (Crawley, 2007a). Two different descriptors of cambial activity as dependent variables were used: presence/absence of cambial activity, and the number of recently formed periclinal cell walls. For presence (1) or absence ( 0 ) of cambial activity, we used a model with binomial error distribution, which explains the factors that are associated with membership of an individual in one class or another (Crawley, 2007b). For the number of recently formed periclinal cell walls (count data), we used a negative binomial error distribution (Crawley, 2007b). Models based on our causal hypothesis included the explanatory variables water availability, day length and temperature (minimum or maximum). Due to the problem of multicollinearity, maximum and minimum temperature were never included in the same models. After 


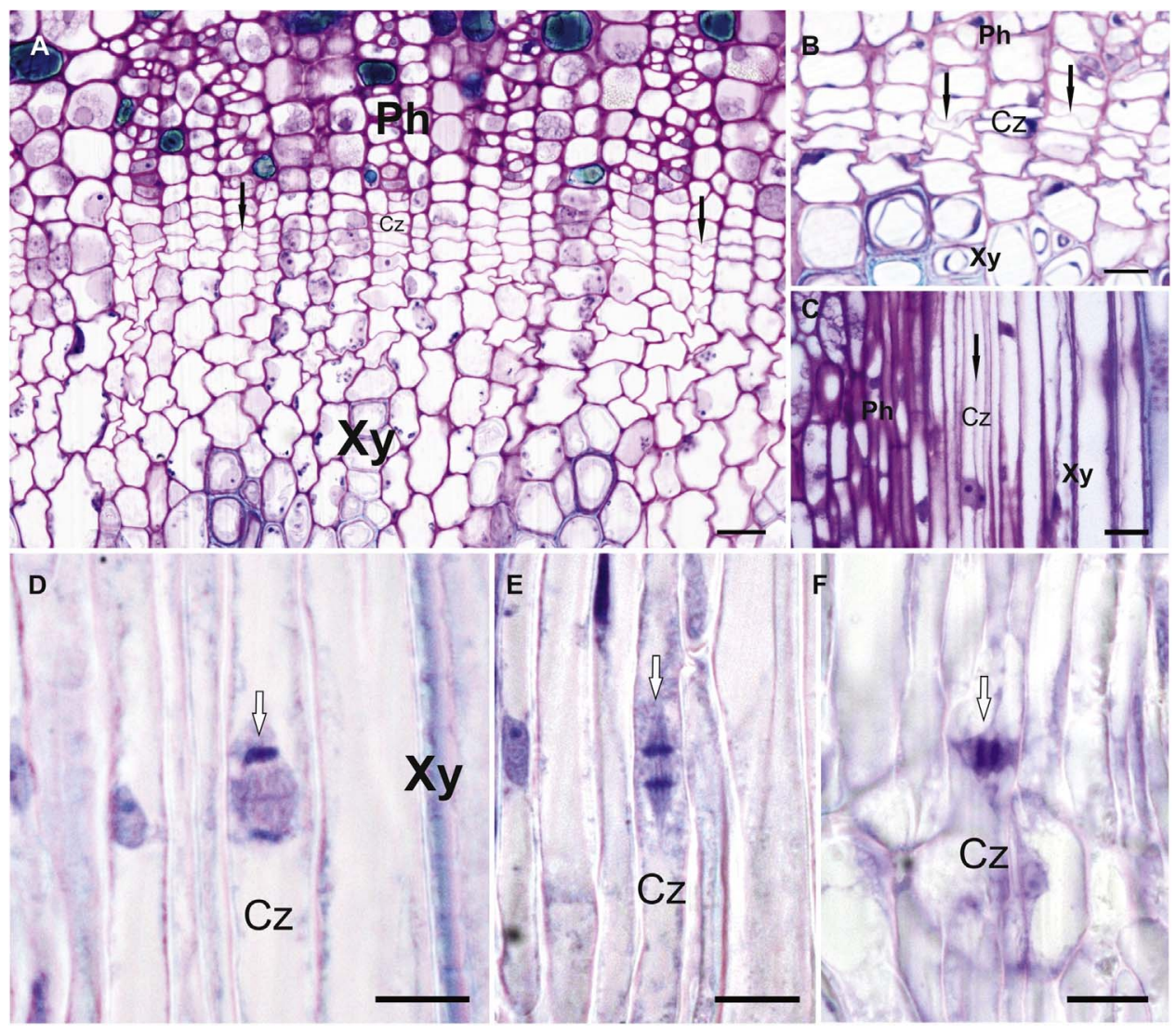

Fig. 3. Cambial activity of Cordiera concolor. A, B Active cambium evidenced by the recently formed periclinal cell walls (black arrows) in transverse section and $\mathbf{C}$ in radial section. D-F Mitotic figures in the active cambial zone in radial sections (white arrows). Labels: Cz: cambial zone; Ph: secondary phloem; Xy: secondary xylem. Scale bars: A, C $20 \mu \mathrm{m}$, B, D-F $10 \mu \mathrm{m}$.

each analysis, we verified the overdispersion before interpreting the significance of effects. Here, we used the scale parameter (the ratio of the residual deviance to the residual degrees of freedom) to describe the overdispersion that is an unexplained variation in the response, where residual deviance is larger than the residual degrees of freedom (Crawley, 2007b). Assuming an appropriate error distribution in each model, both residuals would have similar values and the scale parameter would be around 1 with an excellent best-fit (Crawley, 2007a).

We performed all analyses using the statistical platform $\mathrm{R}$ ( $\mathrm{R}$ Core Team, 2015), the AICcmodavg package (Mazerolle, 2015) for the noncount data, and the MASS package (Vernables and Ripley, 2002) for count data.

\section{Results}

Cambial activity was observed by recently formed periclinal cell walls (Fig. 3A-C) and signs of cell division in the cambial zone were observed in terms of mitotic figures (Fig. 3D-F). Cambial dormancy was observed at the absence of signs of cell division in both transverse and radial sections (Fig. 4A,B), and when the radial walls of fusiform initial cells were thick with numerous pit fields, giving the wall a "beaded" appearance in the tangential section (Fig. 4C). These characteristics of the vascular cambium were recorded during both sampling intervals (early spring and late summer).

\subsection{Cambial activity and variation through early spring and late summer}

The number of plants with an active cambium increased over the weeks in early spring (Fig. 5A) and decreased over the weeks in late summer (marginally statistically significant; Fig. 5B).

There was no clear temporal pattern of variation regarding the number of recently formed periclinal cell walls in either early spring or late summer (Table 2).

\subsection{Effect of water availability on cambial activity}

In early spring, we did not detect a direct effect of water availability on cambial activity (Fig. 6A,C) regardless of the cambial descriptors applied (Table 3), but this effect was positive in late summer. In late summer, the cambium of most plants in the waterlogging treatment remained active during the experiment while the cambium of most plants in the dry regime treatment was dormant (Fig. 6B). The same effect was detected for the number of recently formed periclinal cell walls, with the highest number of thin walls observed in waterlogged plants compared with the other treatments (Fig. 6D, Table 3).

\subsection{Relationship between day length and temperature with cambial activity}

The correlation among pairs of predictors is detailed in the Supplementary data, Table S8, in which the temperature measurements were poorly correlated with day length in both sampling periods (see also Fig. 2). We also did not detect multicollinearity between temperature measurements and day length by the variance inflation factors (VIF) inspection (Supplementary data, Table S9). Given that, we included day length and temperature (maximum or minimum) in the same statistical models for hypothesis testing.

In both sampling periods, cambial activity was positively related to day length and not related to temperature (minimum and maximum), regardless of the cambial descriptors applied (Table 3). In early spring, day length reached $12 \mathrm{~h}$ and $40 \mathrm{~min}$ (Supplementary data, Table S4), increasing by $48 \mathrm{~min}$ from the first to the fifth week. Most plants had their cambium active already in the third week (Fig. 5A) when day length reached $12 \mathrm{~h}$ (Fig. 6A). The greater the day length, the more likely the cambium was active (Fig. 6A; Table 3).

In late summer, day length decreased by $48 \mathrm{~min}$ from the first to the fifth week, to a minimum of $11 \mathrm{~h}$ and $45 \mathrm{~min}$ (Supplementary data, Table S5). The decrease of day length was positively related to cambial dormancy. This pattern was clearly detected in plants under field 


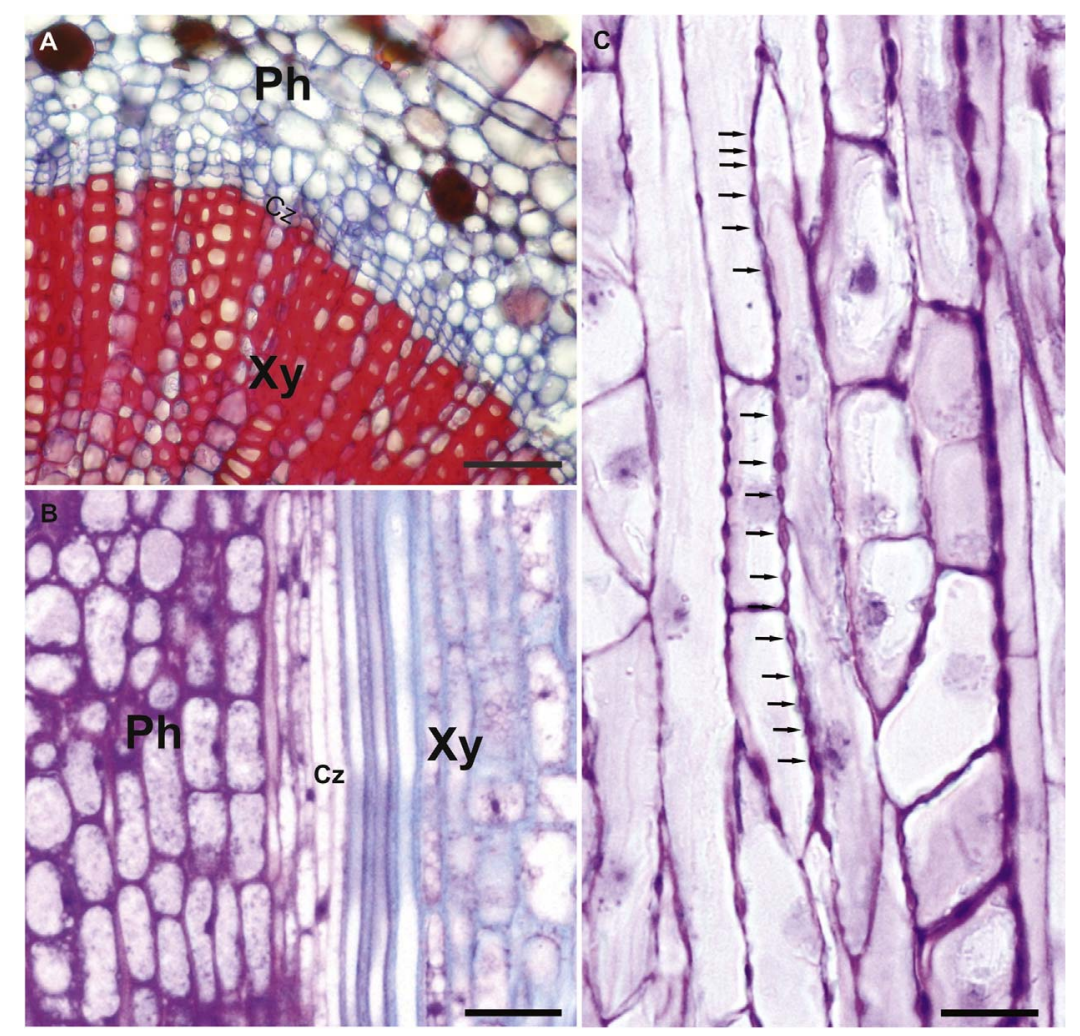

Fig. 4. Cambial dormancy of Cordiera concolor. A Dormant cambial zone in transverse section, with no signs of cell division and thick cell walls. B Dormant cambial zone in radial section. $\mathrm{C}$ Beaded appearance of the radial walls due to the presence of deeply depressed primary pit-fields (arrows) in tangential section. Labels: Cz: cambial zone; Ph: secondary phloem; Xy: secondary xylem. Scale bars: A $50 \mu \mathrm{m}, \mathrm{B}, \mathrm{C} 20 \mu \mathrm{m}$.

capacity (Fig. 5B; Table 3) but less evident in the dry regime and in waterlogged plants. The cambium of most plants was dormant by the fifth week (Fig. 5B), when day length decreased around 20 min from the third week, (Supplementary data, Table S5). Variation in the number of recently formed periclinal cell walls among plants was not explained by day length in either of the sampling intervals (Table 3).

\subsection{Formation of marginal bands of axial parenchyma}

Marginal bands of axial parenchyma (Fig. 7A,B) were observed in wood tissue of Cordiera concolor. Overwintering cells were not observed adjacent to the dormant cambial zone (Fig. 4A; Fig. 7A,C,D) and all xylem cells were fully differentiated during this dormancy period. The layers of differentiating axial parenchyma cells adjacent to the active cambial zone indicate that these bands were recently produced in the beginning of cambial activity (in transverse section, Fig. 7B, and in radial section, Fig. 7E).

\section{Discussion}

Our study provides evidence that the effect of water availability on cambial activity in Cordiera concolor depends on the time of year. In early spring, cambial divisions increased over weeks in most plants following the increase in day length without being affected by changes in water availability. In contrast, in late summer, cambial dormancy was highly related to water availability when day length decreased, affecting only plants under field capacity. Temperature seems to be a less important factor in this system, and did not explain any change in cambial activity during the sampling periods. An unexpected finding of our study was that water availability affects the duration of cambial activity but not the cambium stimulus, which is dependent on day length, and is discussed in detail below.

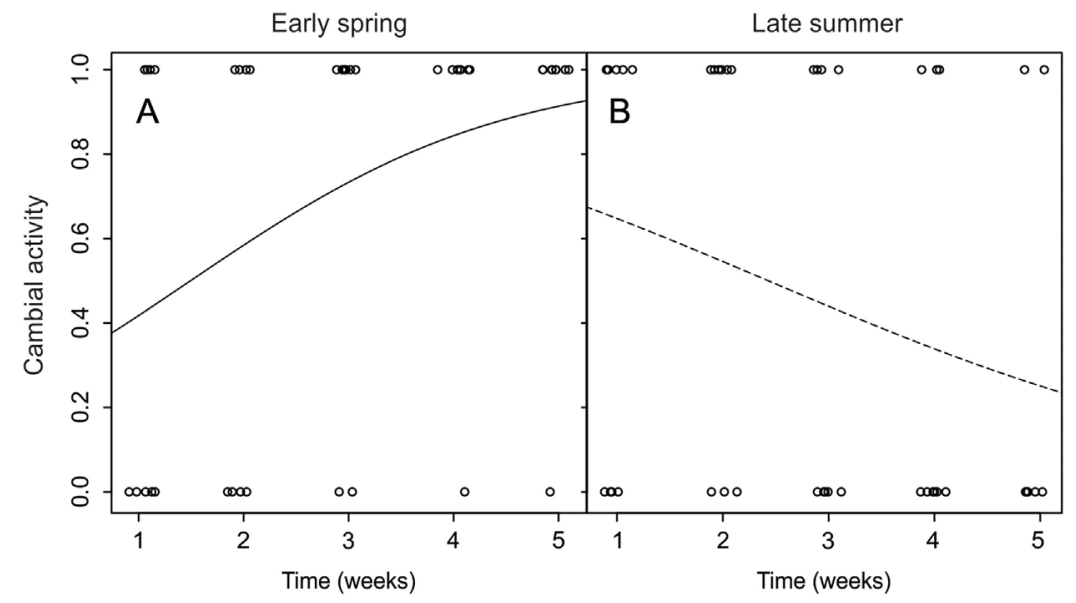

Fig. 5. Correlation between time (weeks) and cambial activity for both sampling intervals. 
Table 2

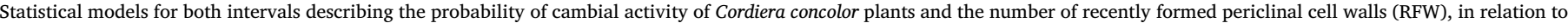
time (weeks). GLM: generalized linear models; BN: binomial negative; RFW: recently formed periclinal cell wall.

\begin{tabular}{|c|c|c|c|c|c|c|c|c|c|c|c|}
\hline Sampling Period & Response & Model & Distribution & Fixed effects & Estimate & SE & $\mathrm{z}$ & $\mathrm{p}$ & $\mathrm{n}$ & Overdispersion & Graphs \\
\hline \multirow[t]{2}{*}{ Early spring } & Cambial activity & GLM & Binomial & Time & 0.6722 & 0.2809 & 2.393 & 0.0167 & 43 & 1.12 & Fig. 5A \\
\hline & Number of RFW & & $\mathrm{BN}$ & & 0.02376 & 0.10957 & 0.217 & 0.82833 & 43 & 1.28 & - \\
\hline \multirow[t]{2}{*}{ Late summer } & Cambial activity & & Binomial & & -0.4255 & 0.2286 & -1.862 & 0.0626 & 45 & 1.35 & Fig. 5B \\
\hline & Number of RFW & & $\mathrm{BN}$ & & -0.09123 & 0.16938 & -0.539 & 0.590 & 45 & 0.99 & - \\
\hline
\end{tabular}

Early spring

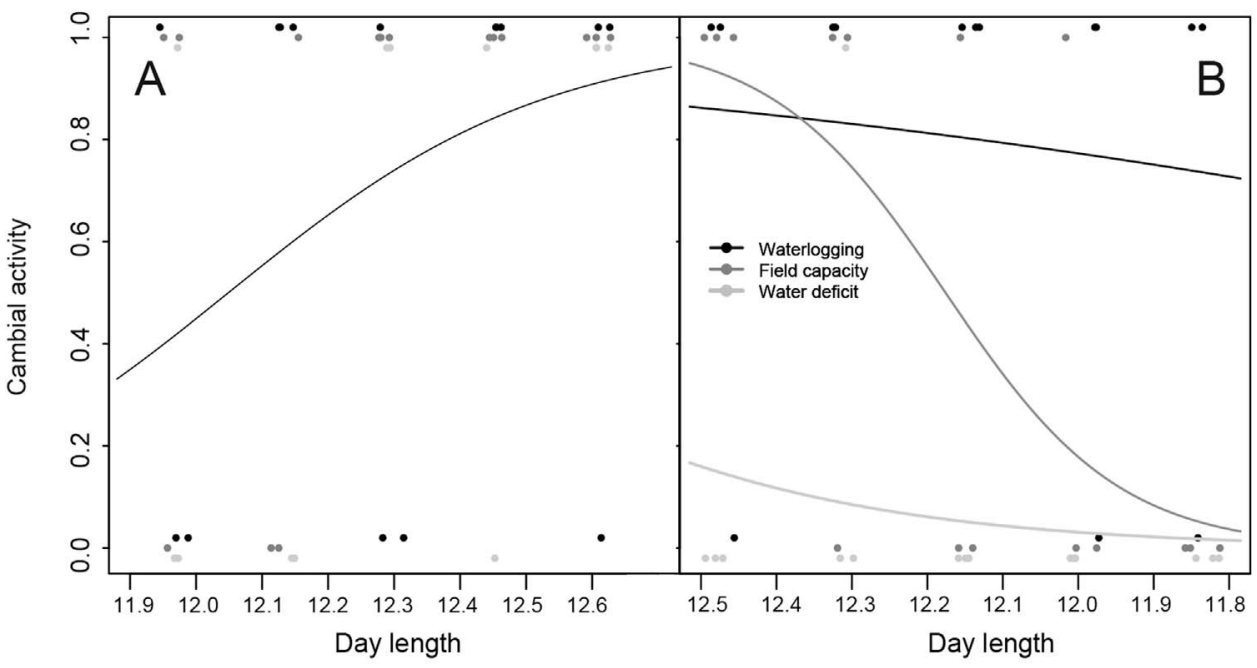

Fig. 6. Correlation between day length, cambial activity and number of recently formed periclinal cell walls for both sampling intervals. The letters $(a, b, c)$ represent statistical test results with $\mathrm{P}^{<} 0.05$.

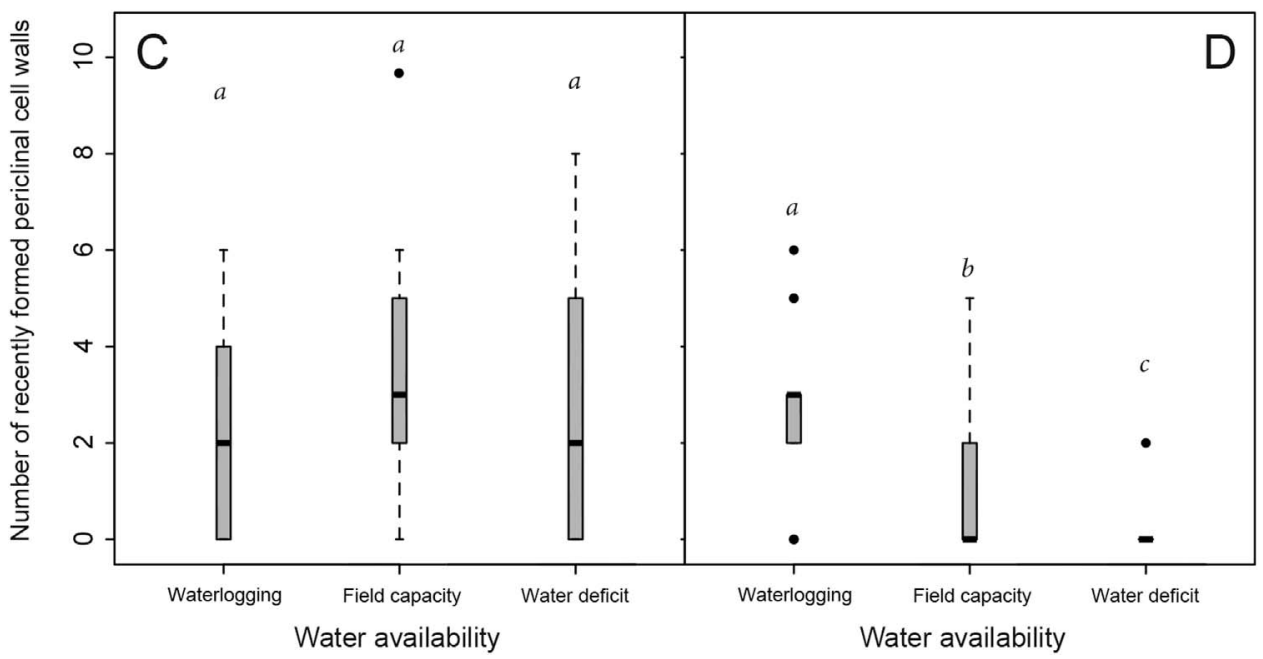

4.1. Day length and water availability as causal factors determining seasonal cambial activity

Seasonal cambial activity was observed in plants of $C$. concolor, an evergreen species, with cambial stimulus in early spring and its deactivation (decrease of cell divisions to dormancy) in late summer. This is in accordance with previous descriptions of cambial activity for many tropical tree species. According to previous studies, cambial activity in tropical species is initiated in early spring (Dave and Rao 1982b; , 2006; , 2008; Paliwal and Paliwal 1990) or in early summer (Ghouse and Hashmi, 1983; Rao and Dave, 1981; Venugopal and Liangkuwang, 2007), whereas the termination of cambial activity has been more variable (late summer, Marcati et al., 2006, 2016; Giantomasi et al., 2012; Trouet et al., 2012; Morel et al., 2015; de Lara and Marcati, 2016; late autumn, Marcati et al., 2008; Bosio et al., 2016; or early winter, Paliwal and Paliwal, 1990; Venugopal and Liangkuwang, 2007). Thus, it seems that the initiation of cambial activity is more predictable than ending, although previous studies did not clarify the factors related to this contrasting pattern between initiation and ending of cambial activity and growth.

In this study, we found that in early spring, day length determined the initiation of cambial activity of $C$. concolor while water availability and temperature were unrelated to it. For this period, we observed that there was an increase in the number of $C$. concolor plants with cambium activity independent of water treatment. We are able to presume that the cambial activity was stimulated by increasing of day length, similar to results reported for three other species from a Mexican subtropical forest with seasonal drought (Yañez-Espinosa et al., 2006).

In late summer, water availability and day length seemed to regulate cambium activity, while temperature remains unimportant. During this period, water supply in the waterlogged soil treatment prevented plants with an active cambium from entering dormancy, 
Table 3

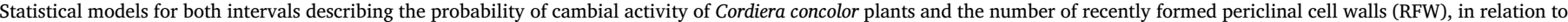

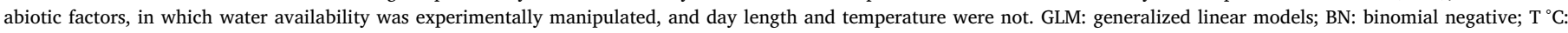
temperature in Celsius; T1: waterlogging soil; T2: field capacity; T3: water deficit.

\begin{tabular}{|c|c|c|c|c|c|c|c|c|c|c|c|c|}
\hline Sampling period & Response variable & Model & Error Distribution & Fixed effects & & Estimate & SE & $\mathrm{z}$ & $\mathrm{p}$ & $\mathrm{n}$ & Overdispersion & Graphs \\
\hline \multirow{10}{*}{ Early spring } & Cambial activity & GLM & Binomial & & Intercept (T2) & -48.28 & 25.11 & -1.92 & 0.05 & 13 & & \\
\hline & & & & Water & $\mathrm{T} 1$ & -0.82 & 0.92 & -0.89 & 0.37 & 13 & & \\
\hline & & & & & $\mathrm{T} 3$ & -1.07 & 0.95 & -1.13 & 0.26 & 13 & 1.21 & Fig. $6 \mathrm{~A}$ \\
\hline & & & & Day length & & 4.14 & 1.89 & 2.19 & 0.03 & 43 & & \\
\hline & & & & Minimum $\mathrm{t}^{\circ} \mathrm{C}$ & & -0.06 & 0.31 & -0.21 & 0.83 & 43 & & \\
\hline & & & & & Intercept (T2) & -49.88 & 29.17 & -1.71 & 0.09 & 13 & & \\
\hline & & & & Water & $\mathrm{T} 1$ & -0.81 & 0.92 & -0.88 & 0.38 & 13 & & \\
\hline & & & & & $\mathrm{T} 3$ & -1.07 & 0.95 & -1.13 & 0.26 & 13 & 1.21 & - \\
\hline & & & & Day length & & 4.24 & 1.96 & 2.16 & 0.03 & 43 & & \\
\hline & & & & Maximum $t^{\circ} \mathrm{C}$ & & -0.03 & 0.38 & -0.07 & 0.95 & 43 & & \\
\hline \multirow[t]{10}{*}{ Early spring } & Number of RFW & GLM & Negative Binomial & & Intercept (T2) & -2.23 & 8.40 & -0.27 & 0.79 & 13 & & \\
\hline & & & & Water & $\mathrm{T} 1$ & -0.33 & 0.35 & -0.92 & 0.35 & 13 & & \\
\hline & & & & & $\mathrm{T} 3$ & -0.21 & 0.36 & -0.58 & 0.56 & 13 & 1.40 & Fig. 6C \\
\hline & & & & Day length & & 0.33 & 0.67 & 0.51 & 0.61 & 43 & & \\
\hline & & & & Minimum $\mathrm{t}^{\circ} \mathrm{C}$ & & -0.05 & 0.11 & -0.42 & 0.67 & 43 & & \\
\hline & & & & & Intercept (T2) & -1.80 & 9.14 & -0.20 & 0.84 & 13 & & \\
\hline & & & & Water & $\mathrm{T} 1$ & -0.33 & 0.35 & -0.92 & 0.36 & 13 & & \\
\hline & & & & & $\mathrm{T} 3$ & -0.20 & 0.36 & -0.56 & 0.58 & 13 & 1.40 & - \\
\hline & & & & Day length & & 0.33 & 0.66 & 0.50 & 0.62 & 43 & & \\
\hline & & & & Maximum $\mathrm{t}^{\circ} \mathrm{C}$ & & -0.04 & 0.13 & -0.34 & 0.74 & 43 & & \\
\hline \multirow[t]{10}{*}{ Late summer } & Cambial activity & GLM & Binomial & & Intercept (T2) & -57.66 & 25.69 & -2.24 & 0.02 & 15 & & \\
\hline & & & & Water & $\mathrm{T} 1$ & 1.89 & 0.97 & 1.96 & 0.05 & 15 & & \\
\hline & & & & & $\mathrm{T} 3$ & -2.89 & 1.25 & -2.31 & 0.02 & 15 & 0.92 & Fig. 6B \\
\hline & & & & Day length & & 4.34 & 2.12 & 2.04 & 0.04 & 45 & & \\
\hline & & & & Minimum $\mathrm{t}^{\circ} \mathrm{C}$ & & 0.25 & 0.45 & 0.56 & 0.57 & 45 & & \\
\hline & & & & & Intercept (T2) & -65.34 & 34.66 & -1.88 & 0.06 & 15 & & \\
\hline & & & & Water & $\mathrm{T} 1$ & 1.88 & 0.96 & 1.95 & 0.05 & 15 & & \\
\hline & & & & & $\mathrm{T} 3$ & -2.88 & 1.25 & -2.31 & 0.02 & 15 & 0.92 & - \\
\hline & & & & Day length & & 4.82 & 2.17 & 2.22 & 0.03 & 45 & & \\
\hline & & & & Maximum $t^{\circ} \mathrm{C}$ & & 0.22 & 0.56 & 0.40 & 0.69 & 45 & & \\
\hline \multirow[t]{10}{*}{ Late summer } & Number of RFW & GLM & Negative binomial & & Intercept (T2) & -9.70 & 9.90 & -0.98 & 0.33 & 15 & & \\
\hline & & & & Water & $\mathrm{T} 1$ & 0.74 & 0.38 & 1.93 & 0.05 & 15 & & \\
\hline & & & & & $\mathrm{T} 3$ & -2.27 & 0.79 & -2.88 & 0.004 & 15 & 1.12 & Fig. 6D \\
\hline & & & & Day length & & 0.93 & 0.83 & 1.12 & 0.26 & 45 & & \\
\hline & & & & Minimum $\mathrm{t}^{\circ} \mathrm{C}$ & & -0.07 & 0.20 & -0.36 & 0.72 & 45 & & \\
\hline & & & & & Intercept (T2) & -8.76 & 14.68 & -0.60 & 0.55 & 15 & & \\
\hline & & & & Water & $\mathrm{T} 1$ & 0.73 & 0.38 & 1.91 & 0.06 & 15 & & \\
\hline & & & & & $\mathrm{T} 3$ & -2.28 & 0.79 & -2.89 & 0.004 & 15 & 1.12 & - \\
\hline & & & & Day length & & 0.81 & 0.86 & 0.95 & 0.34 & 45 & & \\
\hline & & & & Maximum $t^{\circ} \mathrm{C}$ & & -0.03 & 0.25 & -0.12 & 0.90 & 45 & & \\
\hline
\end{tabular}

while the dry regime treatment accelerated the onset of cambium dormancy in most plants. The field capacity treatment showed the strongest evidence of a relationship between decreasing cambial activity and shortened day length. Thus, in late summer period, cambial dormancy although correlated with day length may be advanced (dry regime) or delayed (waterlogging) compared with the field capacity regime. According to Creber and Chaloner (1984), plants will not continue to grow in late summer if water supply is not adequate. Irrigation regimes were experimentally tested by de Luis et al. (2011), who reported a lack of cambial activity in three-year-old plants of Pinus halepensis in dry condition during early summer. In our study, when day length decreased water supply was not enough to maintain cambial activity in plants under field capacity (corresponding to water content in the soil after draining). Using day length as a cue, species may be able to adjust their growth, physiology, and development to the projected future climate change (Lagercrantz, 2009). The cambial dormancy was accelerated in the dry regime since the first week of late summer. Induction of cambial dormancy mediated by dry conditions was reported previously in other experimental studies with temperate species (see Rossi et al., 2009; de Luis et al., 2011; Balducci et al., 2013) When tested in three-year-old plants of Pinus halepensis subjected to different water regimes, cambial dormancy was observed in non-irrigated plants in summer, the warmest period of the year (de Luis et al., 2011).
We found that a water deficit may have advanced cambial dormancy already to the first week of late summer, a period warmer than early spring. Cambial dormancy in late summer seems to be a defense mechanism against severe environmental conditions, similar to the results of Vieira et al. (2015). During summer in the Mediterranean climate of Portugal, these authors found minimum activity in cambial cells of a maritime pine indicating a capacity of some species to adjust cambial activity to environmental conditions (Vieira et al., 2015). In our study, water supply determined the variation of vascular cambium activity with the potential to break the link between dormancy and shorter day length.

While the increase in day length was of great importance for stimulating cambial activity in early spring for $C$. concolor, the reduction of day length in the late summer appeared to stimulate the cambial dormancy. In early spring cambial activity increased with greater day length, whereas in late summer cambial activity decreased with shorter day length. From an ecophysiological perspective, ambient light perception by plants allows the sprouting of new leaves to be induced by a day length increase of $30 \mathrm{~min}$ or less (Rivera et al., 2002). The critical day length for the induction of bud break ranges from 11.5 to $12.5 \mathrm{~h}$ in the subtropics (Rivera et al., 2002). Similarly, our results suggest that a difference of $20 \mathrm{~min}$ or more could stimulate cambial activity of $C$. concolor in early spring while a difference of $20 \mathrm{~min}$ or less could stimulate cambial dormancy in late summer. 


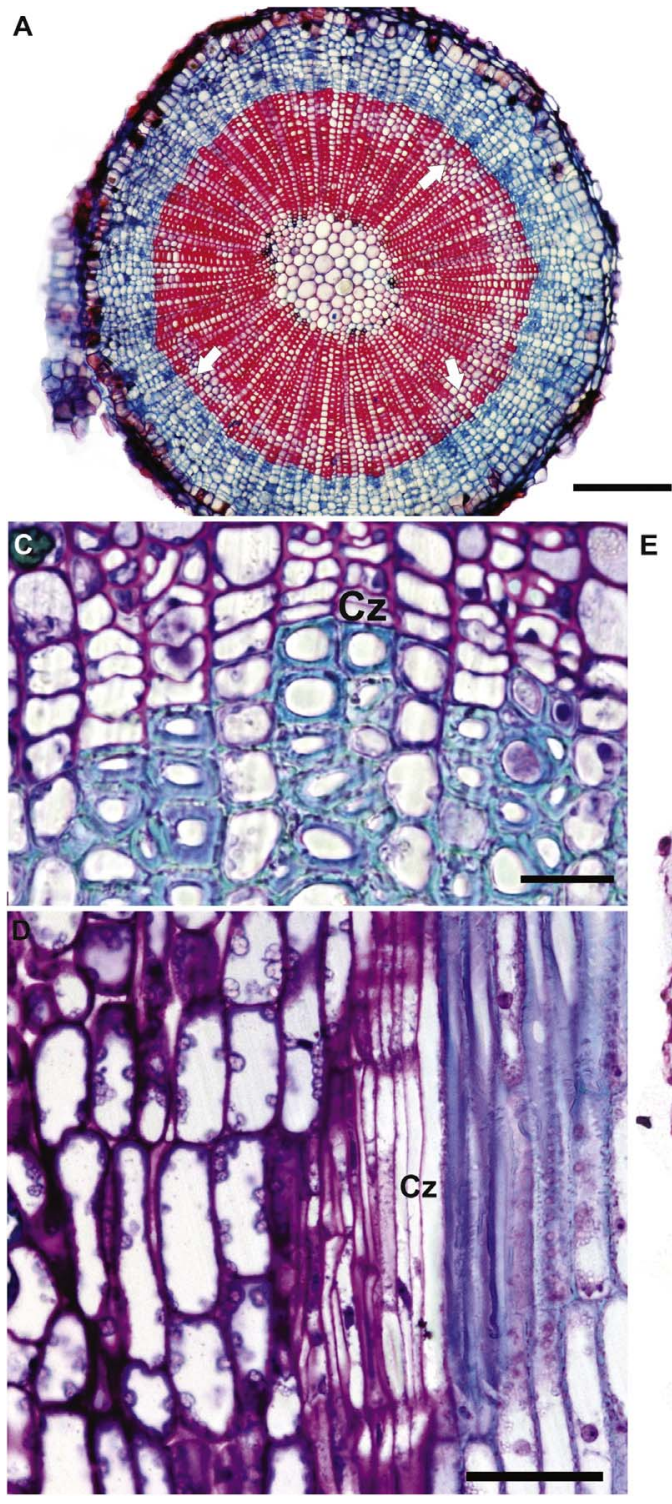

B

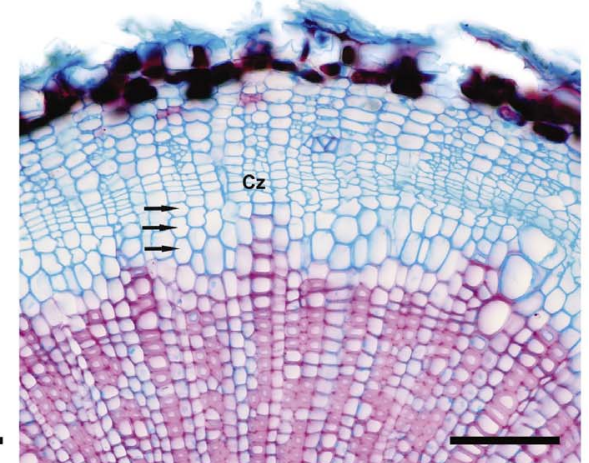

\section{ofit}

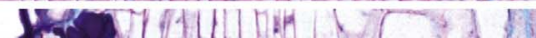

Fig. 7. Growth markers in the wood. A Band of axial parenchyma (arrows) in transverse section. B Axial parenchyma cells in differentiation (arrows) adjacent to cambial zone during the period of cambial activity in transverse section. C Dormant cambial zone and xylem cells adjacent to the cambial zone completely differentiated in transverse section. D Radial section of the same plant as in (A), showing complete differentiation of xylem cells. E Differentiating axial parenchyma cells (arrows) in radial section of the same plant as in (B). Labels: Cz: cambial zone; $\mathrm{Pb}$ : parenchyma band. Scale bars: A $150 \mu \mathrm{m}$, B $100 \mu \mathrm{m}$, D, E $50 \mu \mathrm{m}$, C $20 \mu \mathrm{m}$.
In both sampling intervals, a 12-h day length seems to limit cambial functioning for $C$. concolor. Recently, day length has been suggested as the most important trigger for cambial activity, challenging the assumption that precipitation was the main extrinsic factor driving cambial activity in tropical species (Yañez-Espinosa et al., 2006; Bosio et al., 2016; de Lara and Marcati 2016; Marcati et al., 2016). Day length varies predictably throughout the year, and is a more reliable indicator of season than temperature or precipitation (Lagercrantz, 2009), and can determine many biological cycles in plants such as timing of reproduction (Amasino, 2010) and cambial activity (Marcati et al., 2016). Earlier studies from $70 \mathrm{~s}$ and $80 \mathrm{~s}$ (Waisel and Fahn, 1965; Avila et al., 1975; Creber and Chaloner, 1984; Liphschitz and Lev-Yadun, 1986) indicated a conservative timing of cambial activity, and more recent studies showed it to be under strong genetic control (see Du et al., 2009; Liu et al., 2015). Our experimental study suggests that cambium activity can be predicted by increasing day lengths and cambial dormancy by decreasing day lengths, independent of the temperature variation during the same period. A change in this predictable pattern can be expected when considering cambial activity and the duration of plant secondary growth, which can be strongly altered under different conditions of water availability. Water supply is much less predictable in tropical systems, possibly explaining the large variation in the growth of plants sampled in different years under varying hydrological conditions.

Minimum and maximum temperatures did not explain cambial activity variation in C. concolor in any of our analysis. Although temperature has been recognized as an important environmental factor for cambial activity in temperate species, it seems to have a smaller effect on tropical species. First of all, the temperature variation through time is much less variable in the tropics (here in each sampling period) than in the temperate environment. Hence, temperature was unrelated to cambial activity in four species from a mountain forest of southeastern Ethiopia where the mean temperature is rather constant (Krepkowski et al., 2011), while temperature was positively related to cambial activity in areas where the mean temperature is not constant: three species of subtropical forests in Mexico (Yañez-Espinosa et al., 2006). Dillenia indica (Dilleniaceae) from a subtropical wet forest of northeast India (Venugopal and Liangkuwang, 2007), and Cerrado species from southeastern Brazil (Bosio et al., 2016; Marcati et al., 2016). However, temperature does not act independently, and other factors, such as day length (Yañez-Espinosa et al., 2006, Bosio et al., 2016, Marcati et al., 2016) and precipitation (Bosio et al., 2016; Marcati et al., 2016; Pumijumnong and Buajan, 2012; Yañez-Espinosa et al., 2006), are required for the regulation of cambial activity. In our study, temperature variation was quite constant along each sampling period, while day length and water availability (experimentally defined) were not. 


\subsection{Formation of marginal bands of axial parenchyma}

In our study, layers of undifferentiated axial parenchyma cells were observed adjacent to the active cambial zone (the xylem side) in $C$. concolor at the beginning of the growing season. As there were no overwintering cells adjacent to the dormant cambium in this species, it was clear that the immature axial parenchyma cells were produced by the cambium at the beginning of the growing season. It is appropriate to refer to these parenchyma bands as initial.

The identification of axial parenchyma bands as initial or terminal increases the accuracy of determining the limits of growth rings (Callado et al., 2014) and clarifies the periodicity of growth marker formation. For instance, studies on wood periodicity in Cedrela fissilis have reported axial parenchyma bands to be initial (Boninsegna et al., 1989; Détienne, 1989). A study on the formation of growth rings in the wood of $C$. fissilis showed that these axial parenchyma bands consisted of both terminal and initial parenchyma cells, i.e. parenchyma cells produced at the end of one period of cambial activity and at the beginning of the next, referring to these parenchyma bands as marginal (Marcati et al., 2006). Thus, it is possible to provide useful data for dendrochronological investigations (see Worbes, 1989, 1999; Dunisch et al., 2002), indicating periods of wood production and forest dynamics.

Initial axial parenchyma bands occur in the tropical deciduous trees Cedrela odorata (Dunisch et al., 2002), Schizolobium parahyba (Marcati et al., 2008), and Centrolobium robustum (de Vasconcellos et al., 2016), and in a tropical liana Tynanthus cognatus (Lima et al., 2010). The initial axial parenchyma bands represent a minimal investment of photosynthates in cell wall material at a growing season because there is much more investment in cell wall material (and therefore photosynthates) in latewood than in earlywood (Carlquist, 1980). The initial bands of axial parenchyma could serve as a storage site for the production of new shoots (Carlquist, 1980). High portions of parenchyma tissue (total ray and axial parenchyma) benefit plants in dry conditions by (i) conferring high hydraulic capacitance that could prevent embolism formation and (ii) facilitate embolism refilling (Morris et al., 2016). Cordiera concolor naturally occurs in a seasonally dry ecosystem, such as the Brazilian Cerrado. The high percentage of axial parenchyma bands seem to give the species a certain resilience to damage in dry conditions, not only because of their capacity to store water, but also by providing symplastic connections in axial movement (Morris et al., 2016).

\section{Conclusions}

Our study indicates that day length variation is critical to explain the cambial functioning pattern, on the contrary to temperature variation, and that the influence of different water regimes on cambial activity depends on the period of year. Our results are partially in accordance with previous research stating that precipitation was the main external factor influencing cambial activity in tropical species (Worbes, 1995). In this study, we suggest a more complex scenario of plant functioning and growth patterns in the tropics. We demonstrated that only day length predicted the onset of cambial activity for an evergreen tropical species. In contrast, the expected relationship between day length and cambial activity in late summer was modified in accordance with the water availability, evidencing the essential role of water supply for plant secondary growth continuity. Increased water availability extended cambial activity while less water reduced it, suggesting that plants may be able to adjust their growth to such environmental uncertainty. This could be especially important in seasonally dry areas, where an increase of droughts is expected in the near future and could shorten plant growth periods.

We presented the first data based on a manipulative approach providing evidences for the hierarchy of environmental factors that determine cambial activity in tropical tree species. Although further studies are needed to test the generality of our results, we propose a general model to explain the cambial activity that takes into account the hierarchy of environmental effects for tropical species. In this model, day length is the predominant factor determining the cambial activity, and soil water availability, determined by precipitation and edaphic features, it would be a secondary factor altering the duration of cambium activity and annual growth rate, being variable among years. The temperature variation is less important to tropical species in our model, with the possible exception of tropical sites where its amplitude is highly variable between seasons.

\section{Author contribution statement}

Conception and design of the study: N.O.T. de Lara, M.R. da Silva, C.R. Marcati.

Acquisition of data: N.O.T. de Lara.

Analysis and interpretation of data: N.O.T. de Lara, M.R. da Silva, A. Nogueira, C.R. Marcati.

Drafting the article and revising it critically: N.O.T. de Lara, M.R. da Silva, A. Nogueira, C.R. Marcati.

\section{Acknowledgements}

This work was supported by Fundação de Amparo à Pesquisa do Estado de São Paulo (grant FAPESP - No. 2013/05700-0 to the first author; and funds No. 2015/14954-1 to the last author). We thank Marcos T. Geraldo for assistance with soil collections and with experimental procedures. The nursery at UNESP - Univ Estadual Paulista, Faculdade de Ciências Agronômicas, Botucatu, São Paulo, provided the facilities to conduct this research. This work is the $\mathrm{PhD}$ thesis of the first author.

\section{Appendix A. Supplementary data}

Supplementary data associated with this article can be found, in the online version, at http://dx.doi.org/10.1016/j.envexpbot.2017.07.001.

\section{References}

Abe, H., Nakai, T., 1999. Effect of the water status within a tree on tracheid morphogenesis in Cryptomeria japonica D-Don. Trees 14, 124-129.

Abe, H., Nakai, T., Utsumi, Y., Kagawa, A., 2003. Temporal water deficit and wood formation in Cryptomeria japonica. Tree Physiol. 23, 859-863.

Aljaro, M.E., Avila, G., Hoffmann, A., Kummerow, J., 1972. Annual rhythm of cambial activity in 2 woody species of Chilean matorral. Am. J. Bot. 59, 879-885.

Amasino, R., 2010. Seasonal and developmental timing of flowering. Plant J. 61, 1001-1013.

Avila, G., Aljaro, M.E., Araya, S., Montenegro, G., Kummerow, J., 1975. Seasonal cambium activity of Chilean and Californian shrubs. Am. J. Bot. 62, 473-478.

Balducci, L., Deslauriers, A., Giovannelli, A., Rossi, S., Rathgeber, C.B.K., 2013. Effects of temperature and water deficit on cambial activity and woody ring features in Picea mariana saplings. Tree Physiol. 33, 1006-1017.

Begum, S., Nakaba, S., Yamagishi, Y., Oribe, Y., Funada, R., 2013. Regulation of cambial activity in relation to environmental conditions: understanding the role of temperature in wood formation of trees. Physiol. Plant. 147, 46-54.

Bennett, H.S., Wyrick, A.D., Lee, S.W., Mcneil, J.H., 1976. Science and art in preparing tissues embedded in plastic for light-microscopy, with special reference to glycol methacrylate, glass knives and simple stains. Stain Technol. 51, 71-97.

Berlyn, G.P., Miksche, J.P., 1976. Botanical Microtechnique and Cytochemistry. The Iowa State University Press Ames.

Bertani, D.F., dos Santos, F.A.M., 2013. Regeneração de Psychotria suterella Müll. Arg. (Rubiaceae) em uma paisagem fragmentada de floresta atlântica no sudeste do Brasil 25. Revista do Instituto Florestal, Sao Paulo, pp. 193-203.

Blake, G.R., 1965. Bulk density. In: Black, C.A. (Ed.), Methods of Soil Analysis: Part 1, Physical and Mineralogical Properties, Including Statistics of Measurement and Sampling. American Society of Agronomy Madison, WI, pp. 374-390.

Boninsegna, J., Villalba, R., Amarilla, L., Ocampo, J., 1989. Studies on tree rings, growth rates and age-size relationships of tropical tree species in Misiones, Argentina. IAWA Bull. 10, 161-169.

Borchert, R., 1999. Climatic periodicity, phenology and cambial activity in tropical dry forest trees. IAWA J. 20, 239-247.

Bosio, F., Rossi, S., Marcati, C.R., 2016. Periodicity and environmental drivers of apical and lateral growth in a Cerrado woody species. Trees 30, 1495-1505.

Callado, C.H., Vasconcellos, T.J., Costa, M.S., Barros, C.F., Roig, F.A., Tomazello-Filho, 
M., 2014. Studies on cambial activity: advances and challenges in the knowledge of growth dynamics of Brazilian woody species. An. Acad. Bras. Cienc. 86, 277-284.

Carlquist, S., 1980. Further concepts in ecological wood anatomy, with comments on recent work in wood anatomy and evolution. Aliso 9, 499-553.

Crawley, M.J., 2007a. Generalized Linear Models, The R Book. John Wiley \& Sons, Chichester, pp. 513-526.

Crawley, M.J., 2007b. Binary Response Variables, The R Book. John Wiley \& Sons, Chichester, pp. 593-609.

Creber, G., Chaloner, W.G., 1984. Influence of environmental factors on the wood structure of living and fossil trees. Botanical Rev. 50, 357-448.

de Lara, N.O.T., Marcati, C.R., 2016. Cambial dormancy lasts 9 months in a tropical evergreen species. Trees 30, 1331-1339.

de Luis, M., Novak, K., Raventos, J., Gricar, J., Prislan, P., Cufar, K., 2011. Cambial ac tivity, wood formation and sapling survival of Pinus halepensis exposed to different irrigation regimes. For. Ecol. Manage. 262, 1630-1638.

de Vasconcellos, T.J., Costa, M.S., Barros, C.F., Da Cunha, M., Callado, C.H., 2016. Growth dynamics of Centrolobium robustum (Vell.) Mart. ex Benth. (LeguminosaePapilionoideae) in the Atlantic Forest. Br. J. Bot. 39, 925-934.

Détienne, P., 1989. Appearance and periodicity of growth rings in some tropical woods. IAWA J. 10, 123-132.

Dave, Y.S., Rao, K.S., 1982. Seasonal activity of the vascular cambium in Gmelina arborea Roxb. IAWA Bull. 3, 59-65.

Dié, A., Kitin, P., Kouamé, F.N., Bulcke, J.V., Acker, J.V., Beeckman, H., 2012. Fluctuations of cambial activity in relation to precipitation result in annual rings and intra-annual growth zones of xylem and phloem in teak (Tectona grandis) in Ivory Coast. Ann. Bot. 110, 13.

Du, J., Mansfield, S.D., Groover, A.T., 2009. The Populus homeobox gene ARBORKNOX2 regulates cell differentiation during secondary growth. Plant J. 60, 1000-1014.

Dunisch, O., Bauch, J., Gasparotto, L., 2002. Formation of increment zones and intraannual growth dynamics in the xylem of Swietenia macrophylla, Carapa guianensis, and Cedrela odorata (Meliaceae). IAWA J. 23, 101-119.

Esau, K., 1977. Anatomy of Seed Plants. (New York).

Evert, R.F., 2006. Esau's Plant Anatomy: Meristems, Cells and Tissues of the Plant Body Their Structure, Function and Development. Wiley, New Jersey.

Giantomasi, M.A., Roig-Junent, F., Paton-Dominguez, D., Massaccesi, G., 2012. Environmental modulation of the seasonal cambial activity in Prosopis flexuosa DC trees from the Monte woodlands of Argentina. J. Arid Environ. 76, 17-22.

Ghouse, A.K.M., Hashmi, S., 1983. Periodicity of cambium and the formation of xylem and phloem in Mimusops elengi L, an evergreen member of tropical India. Flora 173, 479-487.

Hoagland, D.R., Arnon, D.I., 1950. The water-culture method for growing plants without soil. Calif. Agric. Exp. Stn. Cir 347, 1-32.

IPCC, 2014. In: Field, C.B., Barros, V.R., Dokken, D.J., Mach, K.J., Mastrandrea, M.D., Bilir, T.E., Chatterjee, M., Ebi, K.L., Estrada, Y.O., Genova, R.C., Girma, B., Kissel, E.S., Levy, A.N., MacCracken, S., Mastrandrea, P.R., White, L.L. (Eds.), Climate Change 2014: Impacts, Adaptation, and Vulnerability. Part A: Global and Sectoral Aspects. Contribution of Working Group II to the Fifth Assessment Report of the Intergovernmental Panel on Climate Change, (Cambridge p. 1132).

Klar, A.E., Villa Nova, N.A., Marcos, Z.Z., Cervélini, A., 1966. Determinação da umidade do solo pelo método das pesagens. Anais da Escola Superior de Agricultura Luiz de Queiroz 23, 15-30.

Krepkowski, J., Bräuning, A., Gebrekirstos, A., Strobl, S., 2011. Cambial growth dynamics and climatic control of different tree life forms in tropical mountain forest in Ethiopia. Trees 25, 59-70.

Lagercrantz, U., 2009. At the end of the day: a common molecular mechanism for photoperiod responses in plants? J. Exp. Bot. 60, 2501-2515.

Lima, A.C., Pace, M.R., Angyalossy, V., 2010. Seasonality and growth rings in lianas of Bignoniaceae. Trees 24, 1045-1060.

Liphschitz, N., Lev-Yadun, S., 1986. Cambial activity of evergreen and seasonal dimorphics around the Mediterranean. IAWA Bull. 7, 145-153.

Little, C.H.A., Savidge, R.A., 1987. The role of plant growth regulators in forest tree cambial growth. Plant Growth Regulation 6, 137-169.

Liu, L., Zinkgraf, M., Petzold, H.E., Beers, E.P., Filkov, V., Groover, A., 2015. The Populus ARBORKNOX1 homeodomain transcription factor regulates woody growth through binding to evolutionarily conserved target genes of diverse function. New Phytologist 205, 682-694.

Marcati, C.R., Angyalossy, V., Evert, R.F., 2006. Seasonal variation in wood formation of Cedrela fissilis (Meliaceae). IAWA J. 27, 199-211.

Marcati, C.R., Milanez, C.R.D., Machado, S.R., 2008. Seasonal development of secondary xylem and phloem in Schizolobium parahyba (Vell.) Blake (Leguminosae: caesalpinioideae). Trees 22, 3-12.

Marcati, C.R., Machado, S.R., Podadera, D.S., de Lara, N.O.T., Bosio, F., Wiedenhoeft, A.C., 2016. Cambial activity in dry and rainy season on branches from woody species growing in Brazilian Cerrado. Flora 223, 1-10.

Mazerolle, M.J., 2015. AICcmodavg: Model Selection and Multimodel Inference Based on (Q)AIC(c), R Package Version 2. (0-3, pp. http://CRAN.R-project.org/ package $=$ AICcmodavg).

Mellerowicz, E.J., Coleman, W.K., Riding, R.T., Little, C.H.A., 1992a. Periodicity of cambial activity in Abies balsamea .1. Effects of temperature and photoperiod on cambial dormancy and frost hardiness. Physiol. Plant. 85, 515-525.

Mellerowicz, E.J., Riding, R.T., Little, C.H.A., 1992b. Periodicity of cambial activity in Abies balsamea. 2. Effects of temperature and photoperiod on the size of the nuclear genome in fusiform cambial cells. Physiol. Plant. 85, 526-530.

Morel, H., Mangenet, T., Beauchene, J., Ruelle, J., Nicolini, E., Heuret, P., Thibaut, B., 2015. Seasonal variations in phenological traits: leaf shedding and cambial activity in
Parkia nitida Miq. and Parkia velutina Benoist (Fabaceae) in tropical rainforest. Trees 29, 973-984.

Morris, H., Plavcova, L., Cvecko, P., Fichtler, E., Gillingham, M.A., Martinez-Cabrera, H.I., McGlinn, D.J., Wheeler, E., Zheng, J., Zieminska, K., Jansen, S., 2016. A global analysis of parenchyma tissue fractions in secondary xylem of seed plants. New Phytologist 209, 1553-1565.

O'Brien, T.P., Feder, N., Mccully, M.E., 1964. Polychromatic staining of plant cell walls by toluidine blue O. Protoplasma 59, 368-373.

Oliveira, D.M.T., 2001. Morfologia comparada de plântulas e plantas jovens de leguminosas arbóreas nativas espécies de Phaseoleae, Sophoreae, Swartzieae e Tephrosieae. Revista Brasileira de Botanica 24, 85-97.

Oribe, Y., Kubo, T., 1997. Effect of heat on cambial reactivation during winter dormancy in evergreen and deciduous conifers. Tree Physiol. 17, 81-87.

Oribe, Y., Funada, R., Shibagaki, M., Kubo, T., 2001. Cambial reactivation in locally heated stems of the evergreen conifer Abies sachalinensis (Schmidt) Masters. Planta 212, 684-691.

Paliwal, S.P., Paliwal, G.S., 1990. Influence of climatic variations on the seasonal behaviour of the vascular cambium in some Himalayan trees. III. Rhododendron arboreum Smith. Phytomorphology 40, 257-271.

Pumijumnong, N., Buajan, S., 2012. Seasonal cambial activity of five tropical tree species in central Thailand. Trees 27, 409-417.

R Core Team, 2015. R: A Language and Environment for Statistical Computing. R Foundation for Statistical Computing, Vienna, Austria. (pp. https://www.R-project. $\operatorname{org} /$.$) .$

Rao, K., Dave, Y., 1981. Seasonal variations in the cambial anatomy of Tectona grandis (Verbenaceae). Nord. J. Bot. 1, 535-542.

Rajput, K.S., Rao, K.S., 2000. Cambial activity and development of wood in Acacia nilotica (L.) DEL. growing in different forests of Gujarat State. Flora 195, 165-171.

Rajput, K.S., Rao, K.S., 2001. Cambial activity and development of xylem in Tamarindus indica L. growing in different forests of Gujarat State. Acta Botanica Hungarica 43, 379-390.

Rajput, K.S., Rao, K.S., 2002. Cambial anatomy and annual rhythm of secondary xylem development in the twigs of Azadirachta indica A. Juss: (Meliaceae) growing in different forests of Gujarat state. J. Sustainable For. 14, 115-127.

Rao, K.S., Rajput, K.S., 1999. Seasonal behaviour of vascular cambium in teak (Tectona grandis) growing in moist deciduous and dry deciduous forests. IAWA J. 20, 85-93.

Richards, L.A., 1948. Porous plate apparatus for measuring moisture retention and transmission by soil. Soil Sci. 66, 105-110.

Rivera, G., Elliott, S., Caldas, L.S., Nicolossi, G., Coradin, V.T.R., Borchert, R., 2002. Increasing day-length induces spring flushing of tropical dry forest trees in the absence of rain. Trees 16, 445-456.

Rossi, S., Simard, S., Rathgeber, C.B.K., Deslauriers, A., De Zan, C., 2009. Effects of a 20day-long dry period on cambial and apical meristem growth in Abies balsamea seedlings. Trees 23, 85-93.

Rossi, S., Anfodillo, T., Čufar, K., Cuny, H.E., Deslauriers, A., Fonti, P., Frank, D., Gričar, J., Gruber, A., King, G.M., 2013. A meta-analysis of cambium phenology and growth: linear and non-linear patterns in conifers of the northern hemisphere. Ann. Bot. 112, 1911-1920.

Sonsin, J.O., Marcati, C.R., Gasson, P., Machado, S.R., Caum, C., 2014. Atlas da diversidade de madeiras do cerrado paulista - Atlas of wood diversity of Cerrado of Sao Paulo. FEPAF - Fundação de estudos e pesquisas agrícolas e florestais, Botucatu.

Time and Date, 2015. Time and Date. (http://www.timeanddate.com/sun/brazil/sao paulo. Retrieved in 23 April).

Trouet, V., Mukelabai, M., Verheyden, A., Beeckman, H., 2012. Cambial growth season of brevi-deciduous Brachystegia spiciformis trees from south central Africa restricted to less than four months. PLoS One 7, e47364.

Venugopal, N., Liangkuwang, M.G., 2007. Cambial activity and annual rhythm of xylem production of elephant apple tree (Dillenia indica Linn.) in relation to phenology and climatic factor growing in sub-tropical wet forest of northeast India. Trees 21, 101-110.

Vernables, W.N., Ripley, B.D., 2002. Modern Applied Statistics with S, fourth ed. Springer, New York.

Vieira, J., Campelo, F., Rossi, S., Carvalho, A., Freitas, H., Nabais, C., 2015. Adjustment capacity of maritime pine cambial activity in drought-prone environments. PLoS One 10, e0126223.

Waisel, Y., Fahn, A., 1965. Effects of environment on wood formation and cambial activity in Robinia pseudacacia L. New Phytologist 64, 436-443.

Wareing, P.F., Roberts, D.L., 1956. Photoperiodic control of cambial activity in Robinia pseudoacacia L. New Phytologist 55, 356-366.

Worbes, M., 1989. Growth rings, increment and age of trees in inundation forests, savannas and a mountain forest in the Neotropics. IAWA J. 10, 109-122.

Worbes, M., 1995. How to measure growth dynamics in tropical Trees - A review. IAWA J. 16, 337-351.

Worbes, M., 1999. Annual growth rings, rainfall-dependent growth and long-term growth patterns of tropical trees from the Caparo Forest Reserve in Venezuela. J. Ecol. 87, 391-403.

Yañez-Espinosa, L., Terrazas, T., Lopez-Mata, L., 2006. Integrated analysis of tropical trees growth: a multivariate approach. Ann. Bot. 98, 637-645.

Zappi, D., 2015. Cordiera, Lista De Espécies Da Flora Do Brasil. Jardim Botânico do Rio de Janeiro, Rio de Janeiro (http://floradobrasil.jbrj.gov.br/jabot/floradobrasil/ FB13891.).

Zuur, A.F., Carvalho, M.F., Ieno, E.N., Saveliev, A.A., Smith, G.M., Walker, N.J., 2009. Negative Binomial GAM and GAMM to Analyse Amphibian Roadkills Mixed Effects Models and Extensions in Ecology with R. Springer, New York. 